\title{
State Model of Interconfessional Tolerance in Modern Multiethnic Societies
}

\author{
Gulnara Shamshudinova, ${ }^{+*}$ Meiramgul Altybassarova, ${ }^{\dagger}$ Galiya Seifullina, $^{\prime}$ Aigul Turlybekova $^{\dagger}$ and \\ Gulsara Dyussembekova $^{\dagger}$
}

\section{Abstract}

The focal point of the article is to examine a way for peaceful coexistence and meaningful dialogue of various ethnicities in the context of Kazakhstan's multiethnic society. There is much evidence that to achieve the goal; it is necessary to establish and justify the principles based on which it is possible to harmonise interfaith relations in the conditions of Kazakhstan state.

The primary concern of the paper is the study of various models of state-confessional relations, and on this basis to formulate recommendations for improving the state model of interconfessional tolerance in modern, multiethnic societies.

The most significant discovery of the research is the idea that the state model of interconfessional tolerance in modern, multiethnic societies emerges from minimising or neutralising the causes that promote the manifestations of intolerant relations. Another important finding is the assumption that it is critical to acknowledge the need to preserve the national, cultural, ethnic, and religious identity in the process of introducing freedom of conscience and religion. The result of the study indicates that it is necessary to introduce legal norms that affirm the real equality of the rights of different faiths in order to overcome the distortions in the assessments of certain faiths and to stimulate the dialogue between the conflicting parties in the religious sphere. No less important is the increased responsibility for the selection of materials regarding the religious sphere in media, as well as, the development of objective assessments of interfaith tolerance.

Keywords: Tolerance, Confessions, State-confessional relations, Interconfessional Relations, Kazakhstan

\footnotetext{
${ }^{\dagger}$ S. Toraighyrov Pavlodar State University, 64, Lomov St., Pavlodar, 140008, Republic of Kazakhstan ${ }^{*}$ Corresponding Author, Email: gulsara.dyusembekova@mail.ru

'̀ Karaganda economic university of Kazpotrebsoyuz 9, Academic St., Karaganda, 100009, Republic of Kazakhstan (C) 2019 Shamshudinova et al.This is an Open Access article distributed under the terms of the Creative Commons Attribution License (http://creativecommons.org/licenses/by/2.0), which permits unrestricted use, distribution, and reproduction in any medium, provided the original work is properly cited.
} 


\section{Introduction}

The concept of interconfessional dialogue is essential for the entire discipline of sociocultural interaction. Recently, there has been a renewed interest in this topic. The need for interconfessional dialogue presupposes the idea of tolerance among the participants of the process and occupies one of the leading places in the sphere of socio-cultural interaction. There is much evidence that the situation of dialogue and tolerant relations are those necessary conditions for solving the problematic issues of the 21st century. They emerge as the cultural and psychological basis on which cooperation and the genuine development of humanity are possible.

The issue of tolerance has received conservable critical attention. The Declaration of Principles of Tolerance, approved by the UNESCO General Conference in November 1995, proclaimed the most generalised, universal, and the world's complete commitment to tolerance as the most acceptable tool for regulating inter-ethnic and interconfessional relations (Declaration of Principles of Tolerance, 1995). It also contains the most extensive modern understanding of tolerance, essential for us to put in the context of a specific problem of inter-confessional relations, which provides:

- ensuring freedom of conscience and freedom of religion for all;

- legal equal rights and equality of opportunity for all, including religious sphere;

- the absence of any discrimination, administrative pressure or violence, the prohibition of rights restriction in connection with ideological or religious beliefs;

- respect for the ability of others to have a different worldview, beliefs, thoughts.

According to the Doctor Habilitatus in philosophy N. L. Vigel (2015), interconfessional tolerance in a multiconfessional, multiethnic society provides:
- the respect and perception of the existing diversity of religions, confessions, religions as diverse forms of self-expression. Respectively, it is assumed that religious self-expression of a person is worthy of being in existence;

- the recognition of legal equality and equality of opportunity for all faiths and religions;

- the respect for the ability of other confessional communities to have a different position, beliefs, judgments, sharing or not sharing them;

- the right of each confessional community to adhere to their convictions and the recognition of the same right for other faiths. At the same time, the observance of such positions reflects a reasonable compromise and not a position of lack of principle. It also does not mean abandoning of one's own religious beliefs or recklessly accepting the beliefs of others;

- the inadmissibility of the assumptions of one's own religious exclusiveness, superiority, domination;

- the non-acceptance and rejection of the governmental policy directed at legal discrimination, restrictions of the rights of other faiths or religious organisations, attempts to politicise the positions of churches and religious organisations;

- the preparedness for practical cooperation with other faiths in socially significant areas of activity, remaining on the principled positions of own's confession and belief (Vigel, 2015).

Eric Nelson concludes that the idea of religious (confessional) tolerance implies a positive and respectful attitude towards representatives of other faiths, the manifestation of religious tolerance (The Religious Origins of Religious Tolerance, 2010).

It is necessary here to clarify that in our study, we understand interfaith tolerance as social 
principles of interaction, which provide for the possibility of observing religious beliefs without any harassment or discrimination.

In our opinion, it will not be possible to completely eradicate religious intolerance, because nobody has done this for centuries. However, everyone must take care of peace in society and not focus on religious differences. In this connection, in the conditions of the multiethnic society of Kazakhstan, it is necessary to find ways of peaceful coexistence and meaningful dialogue. To further improve the situation, it is essential to establish and justify the principles based on which it is possible to harmonise interfaith relations in the context of Kazakhstan state.

Consequently, the study of the current confessional field of the Republic of Kazakhstan in comparison with European countries and the contrastive analysis of contemporary models of religious organisations is significantly relevant today.

In connection with the urgency of the research problem, it was decided to conduct a study of the state of the religious field in the Republic of Kazakhstan, to analyse various models of stateconfessional relations and on this basis to formulate recommendations for improving the state model of interfaith tolerance (Balpanov et al., 2018). The next section discusses the methods and methodological issues deployed in this research.

\section{Methods}

Many researchers have utilised various tools to measure interfaith tolerance. We have developed a special technique to provide qualitative and quantitative statistical data on the religious sphere in the Republic of Kazakhstan. This tool emerges from a careful analysis of the research literature describing the problem field of the study. It contains a content analysis and a survey of experts in this field of research. The benefit of this approach is that it stems from the aim of the article to study the religious field of the Republic of Kazakhstan, as well as to analyse various models of stateconfessional relations, and on this basis formulating recommendations for improving the state model of interconfessional tolerance.

To achieve this goal, we conducted a survey interview with 13 experts in theology and religious studies. This group included six theologians and representatives of the Russian Orthodox Church. It also included seven persons who were graduates of religious studies' department, graduates of secular educational institutions, employees of the University.

Six participants were the experts of Kazakhstan Ministry Department of relations with Islamic religious associations, relations with Christian and other religious associations, members of a special body responsible for the prevention of religious extremism and rehabilitation work, representing the Committee for Religious Affairs of the Ministry of Religious Affairs and Civil Society of the Republic of Kazakhstan.

Criteria for selecting the experts were as follows: the experts must represent all fields of interfaith relations, including the two most prominent religions of Kazakhstan, the scientific community, and government bodies. This principle serves to illuminate the problematic issues of interfaith relations and to provide for the formation of interconfessional tolerance.

\section{Results}

According to the data of the International Center of Cultures and Religions (Republic of Kazakhstan, Nur-Sultan) (March 2018), the confessional field of the country comprises 18 different confessions, numbering more than 3,500 confessional subjects (see, Table 1 ) 


\begin{tabular}{|c|c|c|}
\hline & Confession & The Number of Confessional Subjects \\
\hline 1 & Islam & 2594 \\
\hline 2 & Russian Orthodox Church & 339 \\
\hline 3 & Pentecostalism & 218 \\
\hline 4 & Evangelicalism & 170 \\
\hline 5 & Presbyterianism & 108 \\
\hline 6 & Catholicism & 85 \\
\hline 7 & Jehovah's Witnesses & 48 \\
\hline 8 & Seventh-Day Adventists & 42 \\
\hline 9 & The New Apostolic Church & 26 \\
\hline 10 & Evangelicalic-Lutheran Church & 14 \\
\hline 11 & Bible-Christians & 13 \\
\hline 12 & Krishnaite & 8 \\
\hline 13 & Judaism & 7 \\
\hline 14 & Baha'i faith & 6 \\
\hline 15 & Mennonites & 4 \\
\hline 16 & Buddhism & 2 \\
\hline 17 & Latter-day Saints (Mormons) & 2 \\
\hline \multirow[t]{2}{*}{18} & $\begin{array}{l}\text { the Unification Church and disciples of its } \\
\text { founder, Sun Myung Moon }\end{array}$ & 1 \\
\hline & TOTAL & 3,687 \\
\hline \multicolumn{3}{|c|}{$\begin{array}{l}\text { Sources: International Center of Cultures and Religions } \\
\text { http://www.mckr.kz/ru/\%D0\%BC\%D0\%B8\%D0\%BD\%D0\%B8\%D1\%81\%D1\%82\%D1\%80/item/ } \\
88\end{array}$} \\
\hline
\end{tabular}

Interestingly, at present, there are 3,496 religious buildings in the country, including 2,602 mosques, 300 Orthodox churches, 109 Catholic churches, 396 Protestant churches, as well as 5 Jewish synagogues, 2 Buddhist temples, two prayer houses of the Society for Krishna and the Bahai Community.

Obviously, Islam is the most popular religion in Kazakhstan. Its central representative organisation is the religious association titled "Spiritual Directorate of Muslims of Kazakhstan"
(SDMK), comprising 2,577 branches and 18 offices in regions headed by authorised imams.

Of much importance is the fact that 3,782 imams work in the structure of SDMK (Spiritual Directorate of Muslims of Kazakhstan), 1,424 imams (37.7\%) occupy the posts of principal imams, their deputies (naib-imams) amount to 591 (15.6\%). 504 (14\%) of the imams have a secular education, including 285 (8\%) with higher education and 219 (6\%) with secondary special education (rural imams). 
Undoubtedly, Orthodoxy in Kazakhstan is the second most important religious confession. Its central religious organisation is the Metropolitan District and 330 local religious associations, which include nine dioceses. There is a special clergy educational institution in the country, called the Almaty Orthodox Clergy Seminary (in 2010 the educational establishment was transformed into a seminary), which is the highest theological educational institution within the educational system of the Russian Orthodox Church.

In Kazakhstan, the Catholic church province (Metropolia) also operates 85 Catholic unions, five of which are a branch of the Roman Catholic Church. It is centred on the Roman Catholic Archdiocese of St. Mary in Astana. Two hundred ninety priests of Catholic parishes are officially registered foreign missionaries of the Roman Catholic Church.

The most significant Protestant religious associations in Kazakhstan are Pentecostal churches (219), churches of Evangelical Christian Baptists (175) and Presbyterian churches (108).

At the initiative of the President of the Republic of Kazakhstan N. Nazarbaev in Astana, every three years, beginning from 2003, Kazakhstan holds the Congresses of Leaders of World and Traditional Religions. The participants of the Congresses are the heads of the world's largest confessions, heads of states, prominent politicians, and representatives of international organisations. The next 6th Congress of Leaders of World and Traditional Religions is scheduled for October 2018.

As far as state religious policy is concerned, it is critical to note that the Committee for Religious Affairs coordinates the main directions of the state policy in the religious sphere and interaction with religious associations. The Committee comprises two subordinate organisations, that is, the International Center for Cultures and Religions and the Research and Analytical Center for Religious Affairs. In the regions, there are 15 departments for religious affairs and 21 centres of religious studies.

\section{Discussion}

Experts believe that the confessional diversity of Kazakhstan and the possible emergence of problems in interfaith relations stimulate to seek ways to increase interconfessional tolerance in the Kazakh multiethnic society.

As the experts of the Committee on Religious Affairs indicated in the strategic plan of the Ministry for Religious Affairs and Civil Society of the Republic of Kazakhstan for 2014-2018, one of the problematic issues in the sphere of religion is the insufficiently high level of religious literacy among the population. This situation opens opportunities for various destructive forces of manipulating the consciousness of the citizens of Kazakhstan. To address this issue, religious experts performed information and critical work aimed, inter alia, at strengthening interfaith peace and harmony.

In 2017, the Republican and Regional media released more than 42,000 materials propagating traditional values, the prevention of religious extremism and the formation of immunity against radical ideas in the Republican and Regional media. Kazakhstan TV channels screened more than 110 programs featuring representatives of state bodies, the scientific and expert community members, NGOs and SDMK.

There is evidence to suggest that one of the significant projects in this sphere is the activity of the informational and educational Internet portal "Kazislam" which in 2017 prepared and published more than 5.5 thousand information materials.

In 2017 Kazakhstan launched the blogger project "The organization and conduct of information work in the media to promote secular values and eradicate the ideas of radical religious movements". The managers of the project developed and replicated 60 demotivating projects in social networks and mobile messengers. The project collaborates with such popular communities as "Religious scholars of Kazakhstan", "Religion and modernity", "World of religions", "Oemir zhaily (About life)". 
To create a negative perception of nontraditional religious trends and promote a positive image of the activities of traditional faiths, religious experts introduced the practice of the operative response on the Internet. The Internet response employs new mechanisms of information impact through mobile messengers focused primarily on young people.

In general, in 2017, religious experts generated about 35,000 different formats, covering 2.5 million citizens. As far as youth audience is concerned, religious experts organised more than 13,000 events with the coverage of more than 1 million young people. The measures taken target explaining state policy in the sphere of religion, as well as preventing religious extremism.

The Committee for Religious Affairs provides interaction with the leading religious associations of the country. Together with SDMK, the Committee fights the ideas of radical religious movements and provides the rehabilitation of those believers who have got under the influence of destructive religious movements.

Of much importance is the fact that SDMK framed a special Kazakhstan information and propaganda group. The members of the information and explanatory groups of SDMK held more than 26,000 meetings and reached more than 3.5 million people. These activities resulted in a brilliant achievement when after the meetings with the information and explanatory groups, held for the representatives of destructive religious movements, 940 people refused their radical views.

Nevertheless, in Kazakhstan, the problem of harmonisation of inter-confessional relations on the principles of tolerance remains relevant. The collapse of the Soviet Union led to the establishment of a complicated religious and ideological situation, which is manifested in the gravitation of certain groups to restore the former form of the functioning of religion as a state ideology, which can cause a split in the society. There is much evidence that the problem of identity intensifies the problem of self-identification, and these two issues merge with the cultural and historical context. This often leads to an artificial East-West confrontation embedded in a religious context.

All the above results in the necessity to inquire of state influence experience of maintaining tolerance of interfaith relations in European countries, where the problem of interfaith relations is acute enough in connection with Muslim immigration and the spread of Islam in Europe.

Even though until the 20th Century the process of spreading Islam in Europe was unstable, after the First World War, because of colonial policy, Europe received the first mass migration from the countries of the Muslim East. The influx of Muslims into France during this period increased as a result of the action of three main factors: a) the attraction of labour for the post-war economic recovery; b) the return of freedom of movement to the Algerians; $c$ ) the repatriation of auxiliary troops ( 80 thousand people) after the end of the war in Algeria (Trofimova, 2009). Migrants came individually, without families, since immigration was considered a temporary phenomenon (Chetverikova, 2005).

Currently, Muslim immigration is only increasing, as a result of both multiculturalism policies in Europe and political and military conflicts in Arab countries. For example, the Pew Research Center (USA) published the results of a sociological study "Europe's Growing Muslim Population" (2017) according to which in recent years in Europe, there has been a record influx of asylum-seekers fleeing conflicts in Syria and other predominantly Muslim countries.

According to this study, the Muslim population in Europe (currently it is $28 \mathrm{EU}$ countries plus Norway and Switzerland) as of mid-2016 was 25.8 million people. $(4.9 \%$ of the total population) compared with 19.5 million (3.8\%) in 2010.

The study shows that between mid-2010 and mid-2016, the number of Muslims in Europe increased significantly due to natural growth that is, the birth rate is assumed to have exceeded the number of Muslim deaths by more than 2.9 million people during this period. 
However, most of the growth of the Muslim population in Europe during the period (about $60 \%)$ was due to migration: the Muslim population grew by about 3.5 million due only to migration (Europe's Growing Muslim Population, 2017).

Historically, a relatively small proportion of migrants in Europe are refugees from violence or harassment in their home countries. However, the number of refugees has increased since 2014. For three and a half years from mid-2010 to the end of 2013, about 400,000 refugees arrived in Europe (an average of 110,000 per year). From the beginning of 2014 to the middle of 2016, in just two and a half years, Europe accounted for about three times as many refugees (1.2 million, or about 490,000 per year), since conflicts in Syria, Iraq and Afghanistan continued or intensified. At the same time, these figures do not include additional 970,000 Muslims who are not eligible for refugee status (Europe's Growing Muslim Population, 2017).

As of 2016, according to the Pew Research Center, Muslims constitute $4.9 \%$ of the population of Europe, but in some of the EU countries their share is much higher, for example, in France (8.8\%), Sweden (8.1\%), Belgium (7.6\%), the Netherlands (7.1\%), Austria (6.9\%), Great Britain (6.3\%), Germany (6.1\%) (Europe's Growing Muslim Population, 2017). Thus, the Islamic factor, by which it is customary to understand the politically and socially significant activities of various Muslim entities within a society, state or individual region, has become able to influence the internal situation in those European countries where there is a strong Muslim presence.

Thus, in France at the end of the last century, the number of mosques reached one and a half thousand, and Islamic organisations amounted to about 1,000 . The number of Islamic organisations in Germany is also continually growing, where most German Muslims of Turkish origin are members of Islamic organisations. Moreover, since European Muslims oppose assimilation, the EU countries face a difficult task which is as follows. On the one hand, EU countries must protect their national identity and simultaneously ensure stable economic development. On the other hand, they must promote tolerance of interfaith relations to prevent the growth of religious extremism based on an appropriate model of interconfessional tolerance.

Thus, the model of the relationship between religious organisations and the state in France is somewhat unique. The fundamental principles of this relationship emerge from the relevant Act on the Separation of Churches and the State of 9 December 1905 (Shakhov, 2018), which sets forth the fundamental principles in the first two articles: freedom of religion and lack of recognition and funding. The equality of all religions at the same time implies the absence of a state, official, dominant, or recognised religion.

According to the regime of positive neutrality, presented by the doctrine of "Franch laïcité", the principle of freedom of religion imposes positive obligations on the state, which fall in line with the separation mode. The state must ensure that everyone can attend church services and practice the religion that she/he chooses. During the 20th century, a new understanding of state role began to prevail in France, according to which state intervention is a necessary element which creates required conditions for the public worship of each religion (Davie, 1999). The French regime of "neutral secularism" received a new landmark after the law passed on 15 March 2004. The law prohibits "wearing symbols and clothes that clearly indicate the religious affiliation of students in public schools and lyceums" (Abu-Rabia, 2006: 92; Bowen, 2011: 332).

In general, France has established a separate model for the interaction of state institutions and religious organisations (Maillard, 2010). The country proclaims the fundamental rights to freedom of religion and seeks to limit the prejudiced attitude towards representatives of various faiths. Along with this, the state does not recognise any religion dominant, does not finance any religious cults or associations, does not provide the church with powerful privileges.

As far as Germany is concerned, German religious legislation establishes the principle of 
neutrality, where the state church does not exist (Article 140 of the Basic Law). Each religious community manages its affairs independently according to the common law for all. The state cannot show special affection for a religious confession. This right to self-determination is valid regardless of the legal status of the religious congregation ( German Legal Provisions Relating to Religion in the Federal Republic of Germany, n. d.).

The principle of tolerance obliges the state not only to be impartial to different religious views but also to strengthen positive tolerance, which makes it possible to realise the religious needs of society. Interestingly, parity, the last principle, is the duty to consider all religious communities equal. This means that, despite the constitutional differences in legal status, there is parity, which provides an adequate basis for dealing with various social actors (Weib, Adogame, 2000).

These basic principles underlie religious freedom by article 4 of the Basic Law. This is a requirement of positive tolerance. Freedom of belief is guaranteed to give every person the right to believe what she/he wants. Simultaneously, freedom of belief also includes a negative aspect, which means the right not to profess any religion or not to belong to any religious community. Freedom of religion also provides the possibility for the state to allow interconfessional prayer in state schools to the extent that participation in it is an expression of social relations and is conducted exclusively voluntarily. The state should be sure that such prayer contributes to an atmosphere of tolerance (Kortmann, 2018).

Therefore, in Germany, a cooperative model of interaction between the state and religious organisations emerged. It stems from contractual principles.

Parallel to the German model is the Czech model of state-confessional relations. The Constitution of the Czech Republic guarantees to all citizens freedom of thought, conscience, and religion (Spousta, 2002). Czech state also adheres to the principles according to which it does not identify itself with any church, declares equality and autonomy of various faiths.

Regarding the Slovak approach to different confessions, V. Zozulakova and J. Zozulak defined it as the "middle way" between the rigid separation of church and state and the state church. This model proclaims cooperation and parity relations (Zozulakova, Zozulak, 2010: 50). No confession has the status of a state and does not enjoy privileges (Schneider, 2007). The Constitution declares the Slovak Republic to be a state neutral to any religion and ideology.

The current analysis of interreligious, interconfessional relations in the world indicates that the declarations on the topic of tolerance of these relations and their practical implementation vary. Therefore, conflicts of religious interests permanently find their manifestation in different parts of the world. The conflicts nullify the numerous statements of religious leaders of the highest rank about the importance of tolerance principles.

Durham W. Cole Jr. (2012) suggests that one of the most influential negative factors that impede the establishment of tolerant relations among faiths is the politicisation of the religious sphere and the politicisation of interfaith relations (Durham, 2012).

There is a tendency of intensification of intolerant relations within significant confessions, which, depending on several factors, can eventually lead to the emergence of the group or individual opposition-critical sentiments, splits, divisions, an increase in the so-called. Self-Proclaimed churches, communities, categories of "unchurched" believers who are not organisationally connected with any of the officially existing religious associations. All of the above, according to $A$. De Juan, can cause intergroup (inter-ethnic) or interpersonal conflicts (De Juan, 2015). Often, such changes are the result of restrictions on the freedom of thought within a confessional community, an intolerant ecclesiastical and administrative response to the common belief of ordinary believers, etc. (Aldridge, 2007). 
The current analysis of the world experience of interfaith relations indicates that tolerance, as a set of principles of religious coexistence, which are mandatory for all, does not emerge all by itself. It is rather difficult to hope for the arbitrary approval of tolerance. Existing phenomena and trends, especially present-day economic and financial turmoil, crisis conditions in many countries of the world, make it difficult to achieve this goal (Abdurakhmanov, 2016).

Objectively minded scientists state that as long as we presume existing religious grounds, the most probable scenario is disunity, disintegration process, aspiration for selfisolation, emerging from belonging to different churches, confessions, associations, or religious communities. On the one hand, a common religion unites coreligionists within religious associations or societies. On the other hand, at the same time, a common religion minimises its unifying function, as outside the community of believers, people meet adherents of other religions, and they must prove their advantages, greater truth, etc., that is, , to oppose themselves to all others (Mchedlov, 2004: 176).

In the religious sphere, the urgency of fruitful dialogue and tolerance in interfaith relations is more than obvious (Balpanov et al., 2018). It emerges not only from the understandable unacceptability of conflict or even forceful methods of solving the problematic issues of the religious segment in a globalised society, but also from a whole complex of large-scale, potentially conflictual consequences, generated by radical political, social, spiritual transformations in the countries of the Eurasian space in the 90s of the last century. The global community must overcome these challenges (Muslimova et al., 2017).

In this regard, the question arises in which ways, by what methods and means, it is possible to change the situation with interfaith tolerance for the better. Of much concern is the question of how it is possible to overcome scepticism; what the ways are to ensure a steady process of interfaith tolerance in any objective-subjective hampering circumstances.
According to N. Volodina (2013), the real grounds for professing interfaith tolerance emerge not in the realm of unreal harmonisation of dogmas and canons of some faiths with others, but in the context of conventional, socially significant goals and directions of activity, joint interest in resolving vital universal problems, that is, combating poverty, disease, drug addiction, terrorism, environmental improvement, etc. .

Summarising the above, the state model of interconfessional tolerance in modern, multiethnic societies, in our opinion, stems from the following lines:

- The minimisation or neutralisation of the causes that directly or indirectly, but in all cases, negatively affect the state of interfaith relations. Negative trends promote the manifestation of intolerant relations (politicisation of religion, clericalisation of states and societies, defamation of religions, interference of state structures in interchurch, interfaith relations, extremist actions and fundamentalist-minded believers, religious groups, etc.).

- Preventing the underestimation of the need to preserve national, cultural, ethnic, and religious identity in the process of introducing human rights, freedom of conscience and religion; the deliberalisation of national legislation on freedom of conscience under the pretext of threats to "national security", the loss of "national and cultural identity", etc.

- The transformation of national legislation towards the introduction of legal norms that affirm the real equality of the rights of religious communities, organisations, and associations, and do not allow the elevation of some religions and churches over others, strong legal barriers to discrimination on the ideological and religious grounds.

- Overcoming the distortions in the worldview, ideological, legal, political assessments of certain religions, religious trends; the prevention of the attribution 
of such unreasonable assessments as "terrorist", "destructive", "totalitarian", etc. to individual religious groups. Terrorism cannot and should not be associated with a certain religion, nationality, civilisation, or ethnic group.

- Comprehensive promotion of a dialogue, negotiation process between the conflicting parties in the religious sphere, primarily those that significantly affect the world and regional situation in the religious sphere.

- The increase of professional responsibility for selection and level of materials concerning the religious sphere, the problems of interconfessional relations in mass media. The world witnessed the consequences caused by the publication of caricatures of the Islamic prophet Muhammad.

- State development of objective assessments of interconfessional tolerance relations, overcoming frames which seek to decorate, mitigate the real state of these relations, critical attitude to the "dormant" state of religious conflict.

\section{Conclusion}

The study indicated that the normative and legal acts of the respective state reflect the state model of interconfessional tolerance that depends on several factors of public life. Our principal finding is that the factors of ethnic, political, historical, cultural, spiritual nature have a decisive influence on its formation and functioning.

Another important finding is that tolerance of inter-confessional relations is a set of principles for the coexistence of believers, nonconflict coexistence of religious communities and associations in a multiconfessional and multiethnic society is now the imperative of the time. There is every reason to believe that the course towards tolerance of inter-confessional relations is a single option. Evidently, an effective state model of interconfessional tolerance based on the principles of freedom of conscience and religion is needed; preservation of ethnic and religious identity of all citizens; real equality of the rights of confessions; encouragement of interfaith dialogue; control over the coverage of the religious sphere in the media; suppression of intolerant relations.

\section{References}

Abdurakhmanov, M.A. (2016). The Formation of Students' Tolerance in a Multi-Ethnic School. International Journal of Environmental \& Science Education, 11(3), pp. 269-277.

Abu-rabia, A. (2006). The Veil and Muslim Women in France: Religious and Political Aspects. Anthropology of the Middle East, 1(2), pp. 89-107.

Aldridge, A. (2007). Religion in the Contemporary World: A Sociological Introduction. Cambridge: Polity Press, pp. 256.

Bowen, J. (2011). How the French State Justifies Controlling Muslim Bodies: From HarmBased to Values-Based Reasoning. Social Research, 78(2), pp. 325-348.

Balpanov, N., Ismagambetova, Z., Karabayeva, A., Mirzabekova, A., \& Rysbekova, S. (2018). The Problem of Religious Tolerance in Kazakhstan: Past and Present. Journal Space and Culture, India, 6(2), 17-33. https://doi.org/10.20896/saci.v6i2.318

Chetverikova, O. (2005). Islam v sovremennoy Evrope: strategiya "dobrovolnogo getto" protiv politiki integratsii [Islam in modern Europe: the strategy of a "voluntary ghetto" against the policy of integration]. Russia XXI, 1, pp. 42-87.

Davie, G. (1999). Religion and Laïcité. Modern France: Society in Transition. New York: Routledge, pp. 279.

De Juan, A. (2015). The Role of Intra-Religious Conflicts in Intrastate Wars. Terrorism and Political Violence, 27(4), pp. 762-780.

Durham, W. Cole Jr. (2012). Religious Freedom in a Worldwide Setting: Comparative Reflections. Universal Rights in a World of Diversity. The Case of Religious Freedom 
Pontifical Academy of Social Sciences, pp. 359-389.

Europe's Growing Muslim Population. (2017).

Available at:

http://www.pewforum.org/2017/11/29/eur opes-growing-muslim-population/ (accessed November 11, 2018)

German Legal Provisions Relating to Religion in the Federal Republic of Germany. (n. d.).

Available at: www.uni-

trier.de/fileadmin/fb5/inst/IEVR/Arbeitsmat erialien/Staatskirchenrecht/Deutschland/Reli gionsnormen/German_Legal_Provisions/Ger man_Legal_Provisions_Relating_to_Religion _March_2002.pdf (accessed February 23, 2018)

Kortmann, M. (2018). Debating the integration of Islam': the discourse between governmental actors and Islamic representatives in Germany and the Netherlands. Comparative Migration Studies, 6, pp. 24-35.

Maillard, D. (2010). The Muslims in France and the French Model of Integration. Journal of Middle Eastern and Islamic Studies (in Asia), 4, pp. 1-24.

Mchedlov, M.P. (Ed.). (2004). Tolerance. Moscow: Respublika.

Muslimova, N. N., Sabirov, R. B., Razzhivin, A. I., Komar, N. G., Pashkurov, A. N., Dulalaleva, I. Y. (2017). Approaches to Analyses and Overcoming the Problem of Violence Against Women. Man in India, 97(14), pp. 1-11.

Nelson, E. The Religious Origins of Religious Tolerance. The 2010 Annual Templeton Lecture at the Foreign Policy Research Institute. Available at: www.fpri.org/docs/media/201105.nelson.rel igiousoriginsofreligioustolerance.pdf. (accessed January 20, 2018)

Schneider, J. (2007). Muslim Minorities and Czech Society. In Islam and Tolerance in Wider Europe. Budapest: Open Society Institute, 2007, pp.131-135.
Shakhov, M. (2017). Obieedineniia religioznogo kharaktera v sovremennoi Frantsii [Associations of a religious nature in modern France]. Available at: sdsmp.ru/news/n3456/ (accessed January 20, 2018)

Spousta, J. (2002). Changes in Religious Values in the Czech Republic. Sociologický časopis. Czech Sociological Review, 38(3), pp. 345363.

The Ministry of Religious Affairs and Civil Society of the Republic of Kazakhstan. Available at: diakom.gov.kz/ru (accessed January 20, 2018)

Trofimova, O. (2009). Musulmane i islam v Zapadnoy Evrope [Muslims and Islam in Western Europe]. Mirovaya ekonomika i mezhdunarodnyie otnosheniya [World Economy and International Relations], 10, pp. 52-62.

Declaration of Principles on Tolerance. (16 November 1995). UN Educational, Scientific and Cultural Organisation (UNESCO). Available at: http://portal.unesco.org/en/ev.phpURL_ID =13175\&URL_DO=DO_TOPIC\&URL_S $E C T I O N=201 . h t m l$ (accessed January 20, 2018)

Vigel, N. L. (2015). Tolerantnost kak obshchechelovecheskaia tsennost. Gumanitarnye i sotsialno-ekonomicheskie nauki [Humanitarian and socio-economic sciences], 2(81), pp. 34-37.

Volodina, N.V., (2013). Osobennosti vzaimootnoshenii gosudarstva i religioznykh obieedinenii v stranakh Evropy dlia preodoleniia konfliktov na konfessionalnoi osnove [Legal Initiative]. Pravovaia initsiativa, 3, pp. 483.

WeiB, W., Adogame, A. (2000). The interplay of religion and law in Germany. Religio: revue pro religionistiku, 8(1), pp. 41-64

Zozulakova, V., Zozulak, J. (2010). Religious Education in Slovakia: the new challenges. The International Journal of Educational Researchers, 3(3), pp. 43-56. 